\title{
GANGGUAN KULIT PEMULUNG DI TPA KENEP DITINJAU DARI ASPEK KESELAMATAN DAN KESEHATAN KERJA
}

\author{
DISEASE LEATHER OF SCAVENGER IN KENEP TPA REVIEWED FROM \\ SAFETY ASPECTS AND HEALTH WORK
}

\author{
Karunia Friska Pratama, Corie Indria Prasasti \\ Departemen Kesehatan Lingkungan \\ Fakultas Kesehatan Masyarakat, Universitas Airlangga \\ E-mail: Pram_KFP@yahoo.co.id
}

\begin{abstract}
Scavenger is one of job that have a risk for the health or work safety because they always have interaction with the garbage. Garbage can be source for a disease agent and be a good place for disease vector development. The purpose of this study is to know the skin disease that happens at scavenger from occupational safety and health aspect. The population are 43 people, and the sample amount is 33 people which found from simple random sampling technique. The result showed, based on personal hygiene aspect from 27 scavenger that had skin disease, $96.3 \%$ people had bad condition in their cleanliness at skin, cleanliness at hand, finger, and foot. While from personal protective equipment (PPE) aspect, from 27 people who had skin disease, more than $70 \%$ disease caused by uncleanliness of gloves and shoes that they wear, and $100 \%$ because scavenger never used ganco while work. Some of the reason from this skin disease was fungi, parasite, or environment temperature. The advice for the scavenger was to use Personal protective Equipment (PPE) properly and keep the hygiene and cleaning especially skin hygiene.
\end{abstract}

Keywords: skin diseases, personal protective equipment, personal hygiene

\begin{abstract}
ABSTRAK
Pemulung adalah salah satu jenis pekerjaan yang mempunyai risiko bahaya bagi kesehatan maupun keselamatan kerja karena selalu berinteraksi dengan sampah. Sampah dapat menjadi sumber berkumpulnya kuman penyebab penyakit dan tempat yang baik bagi berkembangbiaknya vektor penyakit. Tujuan dari penelitian ini yakni untuk mengetahui gangguan kulit yang dialami pemulung ditinjau dari aspek keselamatan dan kesehatan kerja. Populasi berjumlah 43 orang dan sampel berjumlah 33 orang yang diambil dengan cara simple random sampling. Hasil penelitian menunjukkan, berdasarkan aspek personal hygiene diketahui dari 27 pemulung yang mengalami gangguan kulit, 96,3\% responden mempunyai kebersihan kulit, kebersihan kaki, kuku dan tangan yang tidak baik. Berdasarkan aspek pemakaian alat pelindung diri (APD), dari 27 responden yang mengalami gangguan kulit, lebih dari $70 \%$ disebabkan oleh pemakaian sarung tangan dan sepatu yang kurang bersih, dan $100 \%$ disebabkan karena responden tidak pernah memakai ganco saat bekerja. Beberapa penyebab dari gangguan kulit tersebut adalah karena jamur, parasit atau suhu udara lingkungan. Anjuran yang disarankan bagi pemulung adalah pemakaian APD sesuai aturan dan menjaga kebersihan diri terutama kebersihan kulit.
\end{abstract}

Kata kunci: gangguan kulit, alat pelindung diri, personal hygiene

\section{PENDAHULUAN}

Terus meningkatnya pertumbuhan penduduk, mobilitas dan juga kegiatan penduduk perkotaan, dapat mengakibatkan lahan untuk tempat pemrosesan akhir sampah juga makin terbatas. Kondisi ini semakin diperberat dengan pengelolaan sampah di masing-masing daerah yang selama ini masih kurang efektif, efisien dan berwawasan lingkungan serta tidak terkoordinasi dengan baik.

Menurut UU RI No. 18 Tahun 2008 tentang Pengelolaan Sampah, tempat pemrosesan akhir atau yang disingkat TPA adalah "Tempat untuk memproses dan mengembalikan sampah ke media lingkungan dengan cara yang aman bagi manusia dan lingkungan". Tempat Pembuangan Akhir (TPA) merupakan lingkungan kerja yang berpotensi memengaruhi kesehatan para pemulung, hal itu disebabkan banyaknya tumpukan sampah yang memungkinkan bakteri dan virus berkembang biak, serta faktor lain seperti faktor fisik, kimia, biologis. Pengelolaan sampah yang kurang baik dapat memberikan pengaruh negatif terhadap kesehatan, 
salah satunya adalah penyakit kulit (Mukono, 2006).

Setiap orang membutuhkan pekerjaan untuk memenuhi kebutuhan hidupnya. Dalam bekerja, keselamatan dan kesehatan kerja merupakan faktor yang sangat penting untuk diperhatikan karena seseorang yang mengalami sakit dalam bekerja akan berdampak pada diri, keluarga, dan lingkungannya.

Di berbagai kota besar di negara berkembang, individu yang tidak mampu bertahan hidup dengan mengumpulkan berbagai bahan bekas, dengan mayoritas mencari bahan yang bisa didaur ulang di tempat pemrosesan akhir sampah yang terbuka. Kelompok pekerja ini mengambil bahan untuk dijual, nantinya dapat digunakan kembali atau diolah ulang. Mereka juga mengumpulkan berbagai macam benda untuk diambil untuk kebutuhan pribadi, dan mereka inilah yang umum disebut sebagai pemulung (Tawee, 2005).

Meskipun tidak terdapat data mengenai kecelakaan atau penyakit akibat kerja di TPA, namun risiko adanya gangguan kesehatan karena paparan berbagai jenis sampah maupun kecelakaan kerja seperti luka ataupun tertimbun oleh sampah sangat mungkin terjadi. Menurut OHSAS 18801, Kecelakaan kerja adalah kejadian yang berhubungan dengan pekerjaan yang dilakukan pekerja yang dapat berakibat cidera atau kesakitan (tergantung keparahannya), dan kejadian yang dapat menyebabkan kematian. Menurut ILO (1990), faktor penyebab terjadinya kecelakaan kerja dapat dibagi menjadi dua kelompok yaitu keadaan yang tidak aman (unsafe condition) dan tindakan /gerakan yang tidak aman (unsafe act). Sedangkan penyakit akibat kerja adalah penyakit yang disebabkan oleh pekerjaan, alat kerja, bahan, proses maupun lingkungan kerja (Badraningsih \& Zuhny, 2013).

Alat Pelindung Diri (APD) adalah seperangkat alat yang dipakai oleh tenaga kerja untuk melindungi dirinya terhadap kemungkinan terdapatnya potensi bahaya serta kecelakaan kerja. Penggunaan APD merupakan suatu usaha untuk menghindari paparan suatu risiko bahaya di suatu tempat kerja. Walaupun penggunaan APD digunakan sebagai upaya pencegahan terakhir dalam usaha melindungi tenaga kerja, namun penerapan alat pelindung diri ini sangat dianjurkan (Tarwaka, 2008).

Penelitian yang dilakukan Mustikawati et al (2012) tentang perilaku pemakaian APD dengan keluhan penyakit kulit di TPA Kedaung Wetan Tangerang, menyatakan bahwa terdapat hubungan yang bermakna antara perilaku penggunaan APD dengan keluhan gangguan kulit pada pemulung di TPA Kedaung Wetan Tangerang, serta dari hasil yang lain juga menyatakan bahwa semakin tinggi perilaku penggunaan APD maka keluhan gangguan kulit yang ditimbulkan juga semakin rendah.

Dari hasil tersebut dapat diketahui bahwa penggunaan APD yang baik dan benar merupakan hal yang penting dilakukan untuk mencegah timbulnya gangguan kesehatan maupun kecelakaan kerja yang dapat terjadi.

Personal hygiene (kebersihan diri/perseorangan) merupakan usaha dari individu atau kelompok dalam menjaga kesehatan melalui kebersihan individu dengan cara mengendalikan kondisi lingkungan (Depkes RI, 2006). Personal hygiene sangat dipengaruhi oleh nilai individu dan kebiasaan, sehingga personal hygiene merupakan hal penting dan harus diperhatikan karena personal hygiene akan memengaruhi kesehatan dan psikis seseorang (Tarwoto, 2004).

Menurut penelitian oleh Sajida (2012) tentang hubungan personal hygiene dan sanitasi lingkungan dengan keluhan penyakit kulit di kelurahan denai kota medan, didapatkan hasil bahwa terdapat hubungan antara personal hygiene, yakni kebersihan kulit, kebersihan kaki, kuku, dan tangan, serta kebersihan pakaian dan handuk dengan timbulnya keluhan penyakit kulit.

Selain penggunaan APD, hal lain yang dapat dilakukan untuk mencegah terjadinya penyakit kulit adalah menjaga kebersihan diri. Selama lebih dari beberapa abad, kebersihan kulit, khususnya kebersihan tangan, telah dipercaya sebagai mekanisme utama untuk mengontrol penyebaran agent penyakit. Walaupun hubungan sebab akibat antara tangan yang terkontaminasi dan penyebaran penyakit infeksi merupakan salah satu fenomena yang terdokumentasi dengan baik di bidang ilmu pengetahuan, namun beberapa faktor lain juga dapat berpengaruh pada kondisi kebersihan kulit (Bianchi, 2011).

Tempat Pemrosesan Akhir (TPA) Kenep berlokasi di Desa Kenep Kecamatan Beji, Kabupaten Pasuruan dan terletak di tepi jalan serta dekat dengan perumahan penduduk sekitar. Sebagian besar pekerja, baik yang bekerja sebagai pemulung atau pekerja formal di TPA Kenep adalah masyarakat yang bertempat tinggal di sekitar TPA.

Di TPA Kenep, cukup banyak pekerja informal atau pemulung yang mencari bahan bekas dan benda yang dapat digunakan kembali atau masih mempunyai nilai jual. Mereka adalah kelompok yang 
mempunyai risiko tinggi mengalami berbagai efek buruk mengingat jenis pekerjaan mereka yang sangat berisiko, dimana kondisi lingkungan kerja pemulung yang berada di lingkungan yang terbuka sehingga memungkinkan terjadinya kontak atau paparan langsung dengan sengatan matahari, debu dan bau dari sampah. Kondisi tersebut dapat menimbulkan risiko gangguan kesehatan seperti penyakit akibat kerja, kecelakaan kerja dan gangguan ergonomi. Dari berbagai hal tersebut, penulis ingin membahas tentang kejadian gangguan kulit pada pemulung ditinjau dari aspek kesehatan dan keselamatan Kerja di TPA Kenep Kabupaten Pasuruan.

\section{METODE}

Rancangan penelitian yang digunakan adalah dengan pendekatan cross sectional study. Penelitian ini bertujuan untuk mengetahui kasus gangguan kulit ditinjau dari faktor keselamatan serta kesehatan kerja kepada pemulung di Tempat Pembuangan Akhir (TPA) Kenep.

Secara khusus, penelitian ini mempunyai tujuan untuk mengetahui angka kejadian gangguan kulit yang dihubungkan dengan pola kepatuhan pemakaian APD dan tingkat personal hygiene pemulung.

Penelitian ini dilakukan di TPA Kenep, yang berlokasi di Kecamatan Beji Kabupaten Pasuruan, dilaksanakan dari bulan Juli-November2016. Populasi dalam penelitian ini adalah pemulung yang berada di TPA Kenep. Penelitian ini memakai cara simple random sampling dan didapatkan jumlah sampel adalah sebanyak 33 orang.

Kegiatan yang dilakukan yakni pemeriksaan medis oleh dokter, meliputi anamnese atau wawancara dan Pemeriksaan fisik untuk menentukan diagnosa gangguan kulit responden, wawancara dan pengisian lembar kuesioner. Data yang diperoleh akan dianalisa dan ditampilkan ke dalam bentuk cross tabulation tabel dan dijelaskan secara deskriptif untuk menjelaskan keadaan gangguan kulit yang dialami pemulung di TPA Kenep.

\section{HASIL}

\section{Gambaran Umum Lokasi Penelitian}

Pemerintah Kabupaten Pasuruan memiliki dua tempat pemrosesan akhir (TPA) yakni TPA Kenep, yang terletak di Kecamatan Beji, dan TPA Rebalas yang terletak di Kecamatan Grati. Hingga saat ini, TPA yang masih beroperasi adalah TPA yang berada di Kenep yang mempunyai luas lahan aktif seluas $26.118 \mathrm{~m}^{2}$.

TPA Kenep berlokasi di Desa Kenep gunungan, berada di dekat jalan raya arah Pandaan Bangil. TPA Kenep menampung sampah yang berasal dari kota di Kabupaten Pasuruan. TPA Kenep beroperasi dari tahun 1989 pada lahan yang berupa jurang yang mempunyai kedalaman $\pm 13 \mathrm{~m}$ (Depression Methode), terletak di lahan seluas 2,5 Ha, dengan menggunakan sistem pengolahan yaitu sistem controlled landfill dengan lapisan geotextile.

Sampah yang dihasilkan oleh masyarakat di Kabupaten Pasuruan lebih didominasi dari daerah komersial seperti pasar, industri, pertokoan, rumah makan dan hotel, serta sekolah, kantor pemerintah, tempat ibadah dan daerah permukiman. Kegiatan Pengangkutan sampah yang dilakukan oleh Dinas Lingkungan Hidup seksi Kebersihan di wilayah Kabupaten Pasuruan adalah kegiatan pengangkutan sampah dari TPS menuju ke TPA.

Pada tingkat TPS pemilahan sampah banyak dikerjakan oleh pemulung serta pekerja pengangkut sampah, sampah yang diperoleh akan dijual kepada pengepul sampah. Untuk kegiatan pengolahan sampah jenis organik di tingkat TPS, dilakukan kegiatan pembuatan kompos oleh Dinas Lingkungan Hidup. Kegiatan tersebut dilaksanakan di beberapa tempat seperti di TPS Pasar Pandaan, Pasar Bangil, Segok, Dermo, Glanggang, Segok, dan PJKA.

Kegiatan pengolahan sampah di TPA Kenep Kecamatan Beji adalah kegiatan pemisahan sampah yang dilakukan dengan cara manual oleh para pemulung yang pada umumnya berasal dari warga sekitar yang bermukim di sekitar wilayah TPA. Selain itu terdapat juga fasilitas rumah kompos untuk mengolah sampah menjadi kompos yang dilakukan oleh petugas TPA. Di sekitar TPA Kenep juga terdapat pondok atau kemah yang dibuat seadanya dari bambu dan kain bekas dan dibangun di atas timbunan sampah untuk digunakan sebagai tempat peristirahatan para pemulung selama bekerja. Kondisi lingkungan tempat pemrosesan akhir sampah yang sangat terbuka dan dikelilingi oleh hamparan sampah yang terdiri dari berbagai jenis dan bercampur menjadi satu.

Kecamatan Beji adalah salah satu kecamatan yang berada di wilayah Kabupaten Pasuruan yang terletak dibagian barat Kabupaten Pasuruan, dengan batas-batas wilayah sebelah utara berbatasan dengan Kecamatan Jabon Kabupaten Sidoarjo, sebelah timur berbatasan dengan Kecamatan Bangil, sebelah selatan berbatasan dengan Kecamatan Pandaan, 
Tabel 1. Hubungan Pemakaian APD dengan Gangguan Kulit Pemulung di TPA Kenep

\begin{tabular}{|c|c|c|c|c|c|c|c|}
\hline \multirow{3}{*}{ Jenis APD } & \multirow{3}{*}{ Pola pemakaian } & \multicolumn{4}{|c|}{ Gangguan Kulit } & \multirow{2}{*}{\multicolumn{2}{|c|}{ Jumlah }} \\
\hline & & \multicolumn{2}{|c|}{ Ada gangguan } & \multicolumn{2}{|c|}{ Tidak Ada } & & \\
\hline & & $\mathrm{n}$ & $\%$ & $\mathbf{n}$ & $\%$ & $\mathbf{N}$ & $\%$ \\
\hline \multirow{2}{*}{ Sarung Tangan } & Selalu menggunakan & 20 & 74,1 & 6 & 100,00 & 26 & 81,8 \\
\hline & Kadang kadang & 7 & 25,9 & 0 & 0,0 & 7 & 18,2 \\
\hline \multirow{2}{*}{ Sepatu } & Selalu menggunakan & 27 & 100,00 & 4 & 66,7 & 31 & 93,9 \\
\hline & Kadang kadang & 0 & 0,0 & 2 & 33,3 & 2 & 6,1 \\
\hline \multirow{2}{*}{ Ganco } & Selalu menggunakan & 0 & 0,0 & 2 & 33,3 & 2 & 6,1 \\
\hline & Tidak pernah & 27 & 100,00 & 4 & 66,7 & 31 & 93,9 \\
\hline
\end{tabular}

Tabel 2. Hubungan Personal Hygiene dengan Gangguan Kulit Pemulung di TPA Kenep

\begin{tabular}{|c|c|c|c|c|c|c|c|}
\hline \multirow{3}{*}{ Personal Hygiene } & \multirow{3}{*}{ Pola pemakaian } & \multicolumn{4}{|c|}{ Gangguan Kulit } & \multirow{2}{*}{\multicolumn{2}{|c|}{ Jumlah }} \\
\hline & & \multicolumn{2}{|c|}{ Ada gangguan } & \multicolumn{2}{|c|}{ Tidak Ada } & & \\
\hline & & $\mathbf{n}$ & $\%$ & $\mathbf{n}$ & $\%$ & $\mathbf{N}$ & $\%$ \\
\hline \multirow{2}{*}{ Kebersihan Kulit } & Baik & 1 & 3,7 & 4 & 66,7 & 5 & 15,2 \\
\hline & Tidak Baik & 26 & 96,3 & 2 & 33,3 & 28 & 84,8 \\
\hline \multirow{2}{*}{$\begin{array}{l}\text { Kebersihan kaki, } \\
\text { kuku dan tangan }\end{array}$} & Baik & 1 & 3,7 & 2 & 33,3 & 3 & 9,1 \\
\hline & Tidak Baik & 26 & 96,3 & 4 & 66,7 & 30 & 90,9 \\
\hline
\end{tabular}

dan sebelah barat berbatasan dengan Kecamatan Gempol.

Berdasarkan data Kecamatan Beji, jumlah penduduk Kecamatan Beji pada saat ini berjumlah 77.983 jiwa yang terdiri dari penduduk laki-laki sebanyak 38.806 jiwa dan penduduk perempuan sebanyak 59.911 jiwa. Sedangkan untuk wilayah Desa Kenep, Jumlah penduduk berdasarkan jenis kelamin tahun 2016, diketahui jumlah penduduk laki-laki berjumlah 1.326 jiwa dan penduduk perempuan berjumlah 2.074 jiwa, sehingga total penduduk yakni 3.400 jiwa.

\section{Hubungan Pemakaian APD dengan Gangguan Kulit}

Dari hasil cross tabulation pada tabel 1 dapat diketahui, berdasarkan pemakaian APD sarung tangan, dapat diketahui dari 27 responden yang mengalami gangguan kulit, sebanyak $74,1 \%$ merupakan responden yang selalu menggunakan sarung tangan saat bekerja. Sedangkan dari 6 responden yang tidak terkena gangguan kulit, 100\% merupakan responden yang selalu menggunakan sarung tangan.
Berdasarkan pemakaian APD sepatu, dapat diketahui bahwa dari 27 responden yang mengalami gangguan kulit, $100 \%$ responden menyatakan selalu menggunakan sepatu saat bekerja, sedangkan dari 6 responden yang tidak mengalami gangguan kulit, $66,7 \%$ responden menyatakan selalu menggunakan sepatu saat bekerja.

Dan dari aspek pemakaian APD ganco, dari 27 responden yang mengalami gangguan kulit, 100\% responden menyatakan tidak menggunakan ganco saat bekerja. Sedangkan dari 6 responden yang tidak mengalami gangguan kulit, 33,3\% responden menyatakan selalu menggunakan alat ganco saat bekerja.

\section{Hubungan Personal Hygiene dengan Gangguan Kulit}

Berdasarkan cross tabulation pada tabel 2, dapat diketahui bahwa dari 27 responden yang mengalami gangguan kulit, 96,3\% merupakan responden yang mempunyai kondisi kebersihan kulit yang tidak baik. Sedangkan dari 6 responden yang tidak mengalami gangguan kulit, 66,7\% mempunyai kondisi kebersihan kulit yang baik. Kondisi kebersihan kulit dinilai dari pemakaian handuk dan 
pakaian, serta perilaku mandi setiap hari. Setiap skor yang didapatkan akan dijumlahkan sehingga akan didapatkan skor akhir yang di kelompokkan menjadi baik dan tidak baik. Kategori tidak baik apabila nilai dari kuesioner kurang lebih sama dengan 24 poin, dimana sebagian besar responden mendapat nilai 22 dan 24, sehingga masuk dalam kategori tidak baik.

Berdasarkan personal hygiene dari aspek kebersihan kaki, tangan, dan kuku, diketahui bahwa dari 27 responden yang mengalami gangguan kulit, 96,3\% responden mempunyai kebersihan kaki, tangan dan kuku yang tidak baik. Sedangkan dari 6 responden yang tidak mengalami gangguan kulit, $33,3 \%$ responden mempunyai kondisi kebersihan kaki, tangan dan kuku yang baik. Kondisi kebersihan tangan, kaki dan tangan dinilai dari beberapa aspek yakni perilaku cuci tangan dan kaki, serta kebersihan kuku responden. Setiap skor yang didapatkan akan dijumlahkan sehingga akan didapatkan skor akhir yang di kelompokkan menjadi baik dan tidak baik.

Kategori tidak baik apabila nilai dari kuesioner kurang lebih sama dengan 17 poin, sebagian besar responden mendapat nilai 17 dan terendah yakni 14 , sehingga masuk dalam kategori tidak baik.

\section{PEMBAHASAN}

\section{Hubungan Pemakaian APD dengan Gangguan Kulit}

Kegiatan pengumpulan data pada variabel penggunaan APD diperoleh dengan kegiatan wawancara berdasarkan instrumen berupa kuesioner dan kegiatan observasi pada pemulung. Pengukuran perilaku penggunaan APD diukur berdasarkan 3 komponen, yakni penggunaan APD sarung tangan, sepatu dan alat bantu ganco.

Anjuran penggunaan APD telah tercantum pada Undang-Undang RI No. 1 Tahun 1970 yang menyatakan bahwa pengurus atau pimpinan tempat kerja berkewajiban menyediakan alat pelindung diri (APD) untuk para pekerja dan para pekerja berkewajiban memakai APD dengan tepat dan benar, dimana tujuan dari peraturan ini adalah untuk melindungi kesehatan pekerja tersebut dari risiko bahaya di tempat kerja. Meskipun pemulung adalah pekerja yang bersifat informal dan tidak mempunyai suatu struktur atau pimpinan yang resmi, namun pemakaian APD sangat penting untuk perlindungan diri, baik dari kecelakaan kerja ataupun penyakit yang disebabkan dari lingkungan kerja. Menurut Mukono (2006), beberapa dampak buruk pada kesehatan akibat pengelolaan sampah yang tidak baik antara lain diare, Dengue Hemorrhagic fever, Pes, penyakit kulit, dan hookworm. Perlindungan diri yang dapat digunakan yakni penggunaan alat perlindungan diri (APD) untuk kepala, wajah, telinga, pernapasan tangan, dan bagian kaki harus tetap diperhatikan sesuai amanat dari Permenakertrans No. 8 Tahun 2010 tentang alat pelindung diri pada pasal 4 yang menyatakan bahwa pemakaian APD wajib digunakan di tempat kerja yang berhubungan dengan pembuangan atau pemusnahan sampah atau limbah.

Dari komponen penggunaan APD sarung tangan diketahui dari 27 responden yang terkena gangguan kulit, 74,1\% merupakan responden yang selalu memakai sarung tangan saat bekerja. Dari hasil tersebut, dapat diketahui bahwa dari kepatuhan responden memakai APD sarung tangan sudah baik, namun dari hasil wawancara dan observasi diketahui bahwa sebagian besar pemulung memakai sarung tangan yang diperoleh dari TPA atau sarung tangan bekas yang kondisinya sudah tidak baik dan pemulung tidak mempermasalahkan jenis dari sarung tangan yang digunakan.

Berdasarkan Permenakertrans Nomor 8 Tahun 2010 tentang alat pelindung diri fungsi alat pelindung tangan adalah untuk melindungi tangan dan jari-jari tangan dari pajanan api, suhu panas, suhu dingin, radiasi elektromagnetik, radiasi mengion, arus listrik, bahan kimia, benturan, pukulan dan tergores, terinfeksi zat pathogen seperti virus dan bakteri serta jasad renik. Menurut Anizar (2012), Macam-macam alat pelindung tangan yaitu Sarung tangan kain, yakni sarung tangan yang digunakan untuk memperkuat pegangan apabila memegang benda yang berminyak, bahan logam lainnya. Sarung tangan asbes yakni sarung tangan yang digunakan untuk melindungi tangan terhadap bahaya pembakaran api. Sarung tangan kulit yakni sarung tangan yang digunakan untuk memberi perlindungan dari ketajaman sudut pada pekerjaan pengecoran. Sarung tangan karet yakni sarung tangan yang digunakan untuk melindungi kulit tangan dari kelembapan air, bahan-bahan zat kimia.

Dari sisi kepatuhan pemakaian APD, sebagian besar sudah tergolong baik dikarenakan pemulung memiliki kesadaran untuk memakai sarung tangan saat bekerja memungut atau mengambil sampah, namun dari sisi kesadaran dan pengetahuan menggunakan APD sarung tangan yang baik, mayoritas responden tergolong kurang. Pemulung menyatakan bahwa pemakaian sarung tangan yang baru maupun bekas tidak terlalu berbeda selama hal 
tersebut masih bisa melindungi tangan mereka saat mengambil sampah.

Mayoritas responden juga menyatakan mereka tidak khawatir kehilangan sarung tangan atau tidak mempunyai sarung tangan, mereka juga menyatakan tidak perlu membeli sarung tangan baru karena mereka dapat mendapatkan sarung tangan tersebut di lokasi TPA, atau memakai sarung tangan bekas. Menurut Tarwaka (2008), beberapa hal yang perlu dipertimbangkan untuk memilih sarung tangan adalah:

Risiko terhadap bahaya yang berada di tempat kerja, berupa bahan yang bersifat korosif, benda atau paparan panas, dingin, kontak dengan benda tajam atau benda keras. Kondisi kekuatan bahan dasar terhadap paparan bahan kimia, contohnya sarung tangan berbahan dasar karet yang alami kurang tepat untuk digunakan pada paparan pelarut organik, hal itu disebabkan karena karet alami larut dalam pelarut organik. Kepekaan objek yang digunakan, seperti pekerjaan yang halus dengan memberikan benda-benda halus lebih tepat menggunakan sarung tangan yang tipis. Bagian tangan yang dilindungi, hanya bagian jari saja, tangan, atau sampai bagian lengan.

Peralatan perlindungan per orangan contohnya sarung tangan, sepatu bot, apron, yang bila dirawat dengan baik dan digunakan secara benar, dapat sangat efektif untuk mencegah penyakit kulit akibat kerja. Namun terdapat keterbatasan dalam penggunaan sarung tangan yakni adanya risiko terjadinya kecelakaan. Jenis sarung tangan yang dipakai harus benar. Memilih jenis sarung tangan yang dipakai berdasarkan jenis bahan kimia yang ditangani dan jenis proses kerja yang dilakukan (Jeyaratnam \& David, 2009).

Berdasarkan hal tersebut, pemakaian APD sarung tangan bekas tidak sesuai dengan fungsi atau kaidah dari alat pelindung tangan sesuai Permenakertrans No. 8 Tahun 2010 tentang alat perlindungan diri, hal tersebut karena sarung tangan bekas tersebut sudah berisiko tinggi mengandung bakteri atau kuman yang justru dapat membahayakan kesehatan tangan dan kulit dan dapat berdampak pada gangguan kesehatan misalnya gangguan kulit.

Hal ini didukung oleh penelitian yang dilakukan Saftarina dkk dalam Robby (2015) yang berjudul hubungan pemakaian alat pelindung diri dan personal hygiene terhadap kejadian dermatitis kontak akibat kerja di TPA Bakung, diketahui bahwa penggunaan APD yang rendah merupakan faktor risiko untuk timbulnya penyakit dermatitis kontak akibat kerja.

Dari aspek pemakaian APD sepatu, diketahui pemulung yang selalu memakai APD sepatu sebanyak 31 orang $(93,9 \%)$.Pemakaian APD sepatu oleh pemulung di TPA Kenep berdasarkan hasil tersebut sudah tergolong baik karena mayoritas sudah memakai sepatu.

Menurut Permenakertrans No. 8 Tahun 2010, fungsi dari alat pelindung kaki adalah melindungi kaki dari tertimpa atau berbenturan dengan bendabenda berat, tertusuk benda tajam, terkena cairan panas atau dingin, uap panas, terpajan suhu yang ekstrem, terkena bahan kimia yang berbahaya, jasad renik dan tergelincir.

Pemakaian APD sepatu yang dilakukan oleh pemulung akan sangat bermanfaat karena banyaknya tumpukan sampah dari berbagai jenis, akan berisiko tinggi menyebabkan cidera atau gangguan kesehatan, namun dari hasil cross tabulation dapat diketahui bahwa dari 27 responden yang mengalami gangguan kulit, $100 \%$ atau semuanya adalah responden yang selalu memakai APD sepatu saat bekerja. Hal ini bertolak belakang dari manfaat dari penggunaan APD sepatu, sehingga dapat disimpulkan bahwa responden tidak menerima manfaat secara penuh dari pemakaian APD sepatu saat bekerja.

Kondisi ini diakibatkan oleh penggunaan APD sepatu yang dilakukan oleh pemulung, dimana mayoritas sepatu yang digunakan pemulung untuk bekerja merupakan sepatu bekas yang diperoleh di TPA atau bekas pakai orang lain yang kondisinya tidak baik. Pemakaian APD sepatu sangat penting karena tidak hanya bertujuan menghindarkan mereka dari luka atau cidera karena benda tajam ataupun benda lain, namun juga menjaga kebersihan dan kontak antara kulit bagian kaki dengan berbagai macam bakteri dan parasit yang ada di sampah.

Berdasarkan jenis pekerjaan yang dilakukan, sepatu keselamatan dibedakan menjadi:

Sepatu pengaman yang digunakan pada pengecoran baja. Sepatu ini terbuat dari bahan baku kulit yang dilapisi oleh krom atau asbes dengan tinggi $\pm 35 \mathrm{~cm}$. Untuk pemakaian sepatu jenis ini, celana dapat dimasukkan ke dalam sepatu lalu dikencangkan dengan menggunakan tali pengikat. Sepatu pengaman pada pekerjaan yang melindungi dari bahaya ledakan. Jenis sepatu ini tidak dianjurkan memakai paku yang berisiko mengakibatkan munculnya percikan api. Sepatu pengaman yang digunakan bagi pekerjaan yang 
kontak dengan listrik. Sepatu ini terbuat dari bahan karet anti elektronik dan tahan terhadap tegangan listrik 10.000 volt selama 3 menit. Sepatu pengaman pada pekerjaan bangunan konsentrasi. Sepatu ini terbuat dari bahan kulit yang dilengkapi dengan baja pada ujung depannya (Tarwaka, 2008).

Sebagian besar pemulung juga tidak memperhitungkan jenis sepatu yang digunakan karena berpikir bahwa pemakaian sepatu bekas tersebut sudah cukup untuk menghindarkan dari benda-benda tajam atau kontak langsung dengan sampah, beberapa pemulung juga memakai kaos kaki yang berlapis dan dalam kondisi yang kotor.

Perilaku tersebut tentunya merupakan perilaku yang tidak sehat dan tidak memberikan manfaat bagi para pemulung tersebut karena paparan pada kaki dan kulit terjadi karena kontak dengan alat pelindung yang digunakan, bukan oleh faktor lingkungan, yang pada akhirnya akan membahayakan kesehatan para pemulung itu sendiri. Hal tersebut tampak dari hasil diagnosis dokter, terdapat pemulung yang mengalami gangguan kulit Tinea pedis, yakni gangguan kulit pada bagian kaki yang disebabkan oleh adanya jamur. Menurut Courtney (2005) praktik memakai sepatu tertutup dalam waktu yang lama dapat menjadi faktor risiko terkena Tinea pedis. Praktik memakai sepatu tertutup dalam waktu yang lama dapat menyebabkan kulit di sekitar kaki lembab karena produksi keringat yang berlebih. Hal inilah yang mendukung jamur tumbuh dengan subur.

Kondisi ini diperkuat dengan penelitian Soekandar dalam Baihaqy (2013) tentang pemakaian sepatu tertutup pada anggota Brimob Semarang. Sesuai dengan penelitian yang telah beliau lakukan pada anggota Brimob Semarang yang selalu memakai sepatu tertutup untuk waktu yang lama, ditemukan angka kejadian Tinea pedis sebesar $24,35 \%$ dari 115 orang anggota Brimob.

Perilaku kesehatan merupakan respons individu yang penting untuk menghadapi gangguan kesehatan, sistem kesehatan, makanan dan lingkungan. Perilaku dari suatu individu atau kelompok dipengaruhi oleh pengetahuan. Faktor yang dapat memengaruhi pengetahuan seseorang atau kelompok adalah edukasi. Edukasi adalah suatu petunjuk yang diberikan seseorang terhadap orang lain mengenai suatu hal yang dapat dimengerti. Pada umumnya, seseorang dengan tingkat edukasi yang lebih tinggi akan lebih mudah untuk menerima informasi yang akhirnya akan lebih banyak pengetahuan yang didapat. Di sisi lain, jika tingkat edukasi seseorang rendah, akan menghambat perkembangan perilaku seseorang untuk menerima informasi dan nilai baru yang didapat (Mubarak et al 2007, dalam Indasah et al 2016). Perilaku pemulung yang menggunakan sepatu dan sarung tangan bekas dapat mencerminkan bahwa kurangnya pengetahuan mengenai pentingnya kebersihan dan keamanan alat pengaman diri yang dipakai.

Berdasarkan aspek pemakaian APD ganco, dapat diketahui sebagian besar pemulung tidak pernah menggunakan alat ganco saat bekerja, yakni 31 orang $(93,9 \%)$. Dari 27 responden yang mengalami gangguan kulit, $100 \%$ merupakan responden yang tidak pernah menggunakan ganco saat bekerja.

Ganco, merupakan alat yang dipakai sebagai pengambil sampah untuk mempermudah pemungutan sampah. Berdasarkan wawancara pada responden, pemulung menyatakan tidak terlalu perlu untuk memakai alat ganco saat bekerja dan lebih sering memakai tangan saat bekerja memilah dan mengambil sampah dan memasukkan ke dalam karung yang dibawa. Pemulung akan memakai alat bantu ganco apabila menemukan alat tersebut atau benda lain yang dapat digunakan sebagai ganco, misalnya kawat besi bekas, ataupun alat cat bekas yang akan dimodifikasi sehingga menyerupai ganco.

Kebiasaan pemulung yang bekerja mengambil dan bersentuhan dengan sampah hampir setiap hari, dapat sangat berbahaya baik dari kesehatan maupun keselamatan kerja pemulung. Penggunaan ganco pada dasarnya juga berfungsi mencegah adanya kontak langsung antara tangan atau kulit pemulung dengan sampah yang kotor yang dapat menyebabkan berbagai macam gangguan kesehatan.

Dari hasil pemeriksaan dokter, didapatkan hasil bahwa diagnosa terbanyak adalah Tinea unguium. Tinea unguium merupakan infeksi jamur yang kronis pada kuku jari kaki atau kuku jari tangan. Biasanya Tinea unguium disertai dengan infeksi jamur yang lama pada kaki. Kuku menjadi tebal, rapuh, dan tidak mengkilat. Tinea unguium (onychomycosis, ringworm of the nail) adalah jamur dermatofitosis yang paling sukar dan lama disembuhkan. Kuku menjadi rusak dan rapuh. Bentuknya tidak lagi normal. Di bagian bawah kuku akan menumpuk sisa jaringan kuku yang rapuh (Smetzer \& Bare, 2002).

\section{Hubungan Personal Hygiene dengan Gangguan Kulit}

Personal hygiene berasal dari kata yunani, berasal dari kata personal yang artinya perorangan dan hygiene berarti sehat (Isro'in dkk, 2012). 
Personal hygiene (kebersihan perorangan) adalah suatu tindakan untuk memelihara kebersihan dan kesehatan seseorang untuk kesejahteraan, baik fisik maupun psikisnya. Faktor-faktor yang memengaruhi personal hygiene diantaranya:

Citra Tubuh, yakni cara pandang seseorang terhadap bentuk tubuhnya, citra tubuh sangat memengaruhi dalam praktik hygiene seseorang.

Praktik Sosial, hal tersebut karena manusia merupakan makhluk sosial dan karenanya berada dalam kelompok sosial. Personal hygiene atau kebersihan diri seseorang sangat memengaruhi praktik sosial seseorang. Selama masa kanak-kanak, kebiasaan keluarga memengaruhi praktik hygiene, misalnya mandi, waktu mandi. Pada masa remaja, hygiene pribadi dipengaruhi oleh kelompok teman sebaya. Pada masa dewasa, teman dan kelompok kerja membentuk harapan tentang penampilan pribadi. Sedangkan pada lansia, akan terjadi beberapa perubahan dalam praktik hygiene karena perubahan dalam kondisi fisiknya.

Status sosial dimana hal tersebut akan memengaruhi jenis dan tingkat praktik hygiene perorangan. Sosial ekonomi yang rendah memungkinkan hygiene per orangan rendah pula.

Pengetahuan dan motivasi, hal tersebut akan memengaruhi praktik hygiene seseorang. Sedangkan motivasi merupakan kunci penting dalam pelaksanaan hygiene tersebut. Permasalahan yang sering terjadi adalah ketiadaan motivasi karena kurangnya pengetahuan.

Budaya, yakni suatu kepercayaan budaya dan nilai pribadi yang akan memengaruhi perawatan hygiene seseorang. Di Asia kebersihan dipandang penting bagi kesehatan sehingga mandi bisa dilakukan 2-3 kali sehari.

Berdasarkan cross tabulation pada tabel 2, dapat diketahui bahwa dari 27 responden yang mengalami gangguan kulit, 96,3\% responden mempunyai kebersihan kulit yang tidak baik. Kategori tidak baik apabila nilai dari kuesioner kurang lebih sama dengan 25 poin, dimana sebagian besar responden mendapat nilai 22 dan 24, sehingga masuk dalam kategori tidak baik.

Perilaku pemulung yang membuat skor yang didapatkan tidak maksimal antara lain masih banyak responden yang memakai handuk bersama dalam satu rumah, misalnya handuk yang dipakai bersama dengan suami atau anak. Perilaku tersebut dapat meningkatkan risiko tertularnya bakteri atau jamur, serta karena kondisi handuk yang lembab.
Perilaku lain yang tampak adalah beberapa pemulung mencuci pakaian lebih dari 2 hari sekali. Hal tersebut tentunya sangat berisiko mengingat paparan yang terjadi di tempat kerja yang penuh dengan sampah, akan menempel dan terdapat di pakaian, yang jika tidak diganti akan membuat paparan ke kulit semakin lama dan akan meningkatkan risiko terjadinya gangguan kulit.

Menurut Hidayat (2008), dalam memelihara kesehatan kulit, kebiasaan yang sehat harus sering diperhatikan seperti: mandi menggunakan sabun mandi secara rutin minimal 2 kali sehari, menggunakan pakaian yang bersih dan rapi (pakaian diganti 1 kali sehari atau jika pakaian sudah kotor atau basah), menghindari penggunaan pakaian, handuk, selimut, sabun mandi, dan sarung tangan secara bersama-sama, menghindari penggunaan pakaian yang lembab atau basah, serta menggosok gigi 2 kali sehari atau sehabis makan.

Hal ini didukung oleh penelitian yang dilakukan oleh Faridawati (2013) tentang hubungan antara personal hygiene dan karakteristik individu dengan keluhan gangguan kulit pada pemulung di Kecamatan Bantar Gebang, yang menyatakan ada hubungan yang bermakna antara kebersihan kulit dengan keluhan gangguan kulit.

Hasil itu juga sejalan dengan pernyataan Hidayat (2008) yang berpendapat bahwa seringkali gangguan pada kesehatan yang dialami seseorang diakibatkan karena kurangnya sikap kebersihan diri yang baik. Beberapa gangguan pada fisik yang umum terjadi yakni gangguan pada kulit seperti penyakit kulit, infeksi mata dan telinga, serta gangguan pada lapisan mukosa mulut, dan kuku. Siahaan (1999) dalam Indriawati (2015) juga berpendapat yakni kurangnya sikap kebersihan seperti tidak mandi dapat menyebabkan buruknya kondisi kebersihan badan, hal tersebut dapat mengakibatkan munculnya gangguan kulit seperti infeksi kulit, skabies, celulitis, panu, jamuran seperti Tinea korporis dan penyakit kulit lain. Meskipun tidak berdampak pada angka kematian, tetapi hal ini dapat mengurangi kualitas kesehatan mereka.

Dari beberapa hal tersebut, sangat penting bagi pemulung untuk menjaga dan merawat kebersihan kulit terutama dari paparan di lingkungan kerja. Perawatan kulit sangat penting untuk dilakukan karena kulit merupakan organ aktif yang berfungsi sebagai organ pertahanan dari bermacam macam kuman atau trauma, tempat sekresi dan ekskresi, mengatur kondisi temperatur dan sensasi, sehingga 
dibutuhkan suatu perawatan yang seimbang dalam mempertahankan fungsinya. Kulit mempunyai 3 jenis lapisan utama yaitu lapisan epidermis, dermis, dan lapisan subkutan. Khususnya pada para pengangkut sampah, perawatan, kulit ini sangat penting diperhatikan karena kondisi pekerjaan yang tidak bersih sehingga meningkatkan kemungkinan akan terkena berbagai macam penyakit seperti penyakit kulit (Tarwaka, 2008).

Berdasarkan aspek kebersihan tangan, kaki dan kuku pada tabel 2, dapat diketahui bahwa dari 27 responden yang mengalami gangguan kulit, $96,3 \%$ merupakan responden yang mempunyai kebersihan tangan, kaki dan kuku yang tidak baik. Kategori tidak baik apabila nilai dari kuesioner kurang lebih sama dengan 17 poin, sebagian besar responden mendapat nilai 17 dan terendah yakni 14, sehingga masuk dalam kategori tidak baik. Hal ini dapat dikaitkan dengan perilaku responden yang sebagian besar memakai sarung tangan dan sepatu bekas sehingga hal tersebut tidak dapat maksimal dalam menjaga kebersihan tangan, kaki dan kuku responden.

Perawatan tangan, kaki dan kuku sering kali membutuhkan perhatian khusus agar dapat mencegah infeksi, bau, dan cidera yang terjadi pada jaringan. Tetapi seringkali orang tidak sadar akan masalah kaki, tangan dan kuku sampai terjadinya nyeri atau ketidaknyamanan. Menjaga kebersihan kuku penting dalam mempertahankan personal hygiene karena berbagai kuman dapat masuk ke dalam tubuh melalui kuku. Oleh sebab itu, kuku seharusnya tetap dalam keadaan sehat dan bersih.

Perilaku pemulung yang mencerminkan kurangnya kebersihan pada tangan, kaki dan kuku adalah pemulung menggunakan cara cuci tangan dengan menggunakan air yang tidak mengalir khususnya saat di tempat kerja atau di TPA, yakni menggunakan baskom yang diisi dengan air, dan tanpa menggunakan sabun. Baskom berisi air tersebut digunakan oleh lebih dari satu pemulung, sehingga risiko berpindahnya kuman atau bakteri dari orang lain juga sangat tinggi.

Kebiasaan pemakaian sarung tangan dan sepatu bekas, pemakaian kaos kaki berlapis yang kotor juga akan berpengaruh pada kebersihan tangan, kaki dan kuku. Dari hasil observasi pada kondisi kebersihan pemulung mayoritas mempunyai kondisi kuku tangan atau kaki yang kotor dan tampak hitam.

Menjaga kebersihan tangan, kuku, dan kaki merupakan salah satu aspek penting dalam mempertahankan kesehatan badan perseorangan, oleh karena itu tangan, kuku, dan kaki harus dijaga kebersihannya. Kuman penyakit dapat terbawa melalui tangan, kuku, dan kaki yang kotor. Tangan, kaki, dan kuku yang kotor membawa bibit penyakit. Bibit penyakit dan telur cacing yang mungkin ada dalam tangan atau kuku yang kotor ikut tertelan. Sebagian masyarakat mengetahui akan pentingnya mencuci tangan dengan memakai sabun, tetapi dalam praktiknya sehari hari masih sangat sedikit yang tahu bagaimana cara melakukannya dengan benar. Cuci tangan adalah cara yang efektif untuk mencegah terjadinya penyebaran mikroorganisme (Sundari, 2014).

Mencuci tangan sebaiknya dilakukan sesudah ke WC, sebelum membuat atau menyajikan atau makan makanan, setelah menyentuh sampah, setelah beraktivitas (Jerusalem, 2010). Untuk menjaga kebersihan tangan, kaki, dan kuku dengan cara membersihkan tangan sebelum makan, memotong kuku secara teratur, mencuci kaki sebelum tidur dan membersihkan lingkungan.

Hal itu didukung oleh penelitian yang dilakukan oleh Sajida (2012) tentang hubungan personal hygiene dan sanitasi lingkungan penduduk Kelurahan Denai Kota Medan dengan keluhan penyakit kulit, menyatakan terdapat hubungan yang bermakna antara kebersihan tangan, kaki, dan kuku terhadap keluhan penyakit kulit di masyarakat Kelurahan Denai.

\section{SIMPULAN}

Berdasarkan kegiatan penelitian yang telah dilakukan dan analisa data dengan menggunakan cross tabulation, maka dapat disimpulkan:

Hasil pemeriksaan medis pada 33 responden, didapatkan data sebanyak 27 responden $(81,8 \%)$ mengalami gangguan kulit.

Berdasarkan perilaku pemakaian APD sarung tangan, dari 27 responden yang mengalami gangguan kulit, 74,1\% responden menyatakan selalu menggunakan APD sarung tangan saat bekerja.

Berdasarkan perilaku pemakaian APD sepatu, dari 27 responden yang mengalami gangguan kulit, $100 \%$ responden menyatakan selalu menggunakan APD sepatu saat bekerja.

Berdasarkan perilaku pemakaian ganco, dari 27 responden yang mengalami gangguan kulit, 100\% responden menyatakan tidak pernah memakai ganco saat bekerja. 
Berdasarkan perilaku personal hygiene, dari 27 responden yang mengalami gangguan kulit, 96,3\% responden merupakan responden yang memiliki kebersihan kulit, kebersihan kaki, tangan dan kuku yang tidak baik.

\section{DAFTAR PUSTAKA}

Anizar. 2012. Teknik Keselamatan dan Kesehatan Kerja di Industri. Yogyakarta: Graha Ilmu.

Badraningsih L, Enny Zuhny. Kecelakaan Akibat Kerja (KAK) dan Penyakit Akibat Kerja (PAK). Diakses di http//: www.staff.uny.ac.id-sites-filespendidikan, pada 30 Januari 2017.

Bianchi, J. 2011. Common Skin Conditions Explained. Independent Medical Education Specialist NHS Scotland.

Courtney, M.R. 2005. Tinea Pedis. Diakses dari http//: www.emedicine.com, pada 30 Januari 2017

C, Smetzer \& G, Bare. Buku Ajar Keperawatan Medikal-Bedah. Brunner \& Suddarth. Edisi 8; Vol. 3, Jakarta: EGC.

Depkes Republik Indonesia. 2006. Profil Kesehatan Indonesia. Jakarta. Diakses dari www.depkes. go.id-download sitasi tanggal 1 Februari 2017.

Faridawati, Yeni. 2013. Hubungan antara Personal Higiene dan Karakteristik Individu dengan Keluhan Gangguan Kulit pada Pemulung (Laskar Mandiri) di Kelurahan Sumur Batu Kecamatan Bantar Gebang. Skripsi. Universitas Islam Negeri Syarif Hidayatullah Jakarta. Sitasi tanggal 1 Februari 2017.

Hakim, Muhammad B.I. 2013. Prevalensi dan Faktor risiko terjadinya tinea pedis pada pekerja pabrik tekstil. Jurnal Media Medika Muda. Diakses dari www.download.portalgaruda.org tanggal 1 Februari 2017.

Hidayat,AzizAlimul. 2008. Keterampilan Dasar Praktik Klinik untuk Kebidanan. Jakarta: Salemba.

Indasah, N.Z.M., Prima, D.K. 2016. Relationship of Behavior in the Use of Personal Protective Equipment (APD), Eating A Healthy and Balanced, and Personal Hygiene to Health Status of Skin on Scavenger in TPA Kediri. J. Appl. Environ. Biol. Sci., 6(2)1-5, 2016. sitasi pada 30 Januari 2017.

Indriastuti, D., Handono, H.P. 2015. Hubungan Personal Hygiene dengan Kejadian Penyakit kulit di TK Ngadirejo Kidul, Wonogiri. Diakses dari www.journal.akpergshwng.ac.id-article-view. Sitasi tanggal 1 Februari 2017.

Isro'in, L., Sulistyo. 2012. Personal Hygiene, Konsep, Proses dan Aplikasi dalam Praktik Keperawatan. Yogyakarta: Graha Ilmu.

Jerusalem, Mohammad Adam. 2010. Modul Keselamatan dan Kesehatan Kerja. Yogyakarta: UNY. Diakses dari http//: www.staff.uny.ac.idsites-files-pendidikan tanggal 1 Februari 2017.

Jeyaratnam, J., David, K. 2009. Buku Ajar Praktik Kedokteran Kerja. Alih bahasa oleh Suryadi. Jakarta: Penerbit EGC.

Mukono, H.J. 2006. Prinsip Dasar Kesehatan Lingkungan. Surabaya: Airlangga University Press.

Mustikawati I. S, Budiman F, \& Rahmawati. 2012. Hubungan Perilaku Penggunaan Alat Pelindung Diri (APD) dengan Keluhan Gangguan Kulit di TPA Kedaung Wetan Tangerang. Forum Ilmiah Volume 9 Nomor 3, September 2012.

OHSAS 18001:2007 Occupational Health and Safety Management System - Requirements.

Peraturan Menteri Tenaga Kerja dan Transmigrasi Nomor 8 tahun 2010 tentang Alat Pelindung Diri.

Pemerintah Kabupaten Pasuruan. 2013. Buku Sanitasi Kabupaten Pasuruan. Diakses di http://www.ppsp nawasis info. (Sitasi Tanggal 20 Januari 2017).

Robby, P. 2015. Association between Personal Protective Equipment with Contact Dermatitis in Scavengers. J Majority Volume 4 Nomor 4 Februari 2015. Sitasi tanggal 31 Januari 2017.

Sajida, Agsa. 2012. Hubungan Personal Hygiene dan Sanitasi Lingkungan Penduduk Kelurahan Denai Kecamatan Medan Denai Kota Medan Tahun 2012 dengan Keluhan Penyakit Kulit. Skripsi. Fakultas Kesehatan Masyarakat Universitas Sumatera Utara.

Siregar, R.S. 2004. Penyakit Jamur Kulit Ed 2. Jakarta: EGC

Sundari, Cok D.W.H, I Wayan Merta, Dewi Sarihati. 2014. Hubungan Faktor Predisposisi, Pemungkin, dan Penguat dengan Praktik Cuci Tangan Serta Keberadaan Mikroorganisme pada Penjamah Makanan di Pantai Kedonganan. Jurnal Skala Husada. Volume 11 Nomor 1 April 2014.

Tarwaka. 2008. Keselamatan dan Kesehatan Kerja Manajemen dan Implementasi K3 di Tempat Kerja. Surakarta: Penerbit Harapan Press. 
Tarwoto, Wartonah. 2004. Kebutuhan Dasar Manusia dan Proses Keperawatan edisi 3. Jakarta: Salemba.

Tawe, S. 2005. Challenges of Scavenger in Malaysia. Department of Construction and Property
Management. Diakses dari http//: eprints.uthm. edu.my (Sitasi tanggal 23 Januari 2017).

Undang-Undang No. 1 Tahun 1970 tentang Keselamatan Kerja.

Undang-Undang RI No. 18 Tahun 2008 tentang Pengelolaan Sampah. 